\title{
Total Carbon Stock and Potential Carbon Sequestration Economic Value of Mukogodo Forest-Landscape Ecosystem in Drylands of Northern Kenya
}

\author{
Nereoh C. Leley ${ }^{1,2 *}$, David K. Langat ${ }^{1}$, Abdalla K. Kisiwa1, Geoffry M. Maina², Meshack 0. Muga ${ }^{1,3}$ \\ ${ }^{1}$ Kenya Forestry Research Institute, Nairobi, Kenya \\ ${ }^{2}$ Department of Natural Resources, Egerton University, Njoro, Kenya \\ ${ }^{3}$ Food and Agriculture Organization of the United Nations, Nairobi, Kenya \\ Email: *nereoh24@gmail.com, lnereoh@kefri.org
}

How to cite this paper: Leley, N. C., Langat, D. K., Kisiwa, A. K., Maina, G. M., \& Muga, M. O. (2022). Total Carbon Stock and Potential Carbon Sequestration Economic Value of Mukogodo Forest-Landscape Ecosystem in Drylands of Northern Kenya. Open Journal of Forestry, 12, 19-40. https://doi.org/10.4236/ojf.2022.121002

Received: October 3, 2021

Accepted: November 19, 2021

Published: November 22, 2021

Copyright $\odot 2022$ by author(s) and Scientific Research Publishing Inc. This work is licensed under the Creative Commons Attribution International License (CC BY 4.0).

http://creativecommons.org/licenses/by/4.0/

(c) (i) Open Access

\begin{abstract}
Carbon sequestration is one of the important ecosystem services provided by forested landscapes. Dry forests have high potential for carbon storage. However, their potential to store and sequester carbon is poorly understood in Kenya. Moreover, past attempts to estimate carbon stock have ignored drylands ecosystem heterogeneity. This study assessed the potential of Mukogodo dryland forest-landscape in offsetting carbon dioxide through carbon sequestration and storage. Four carbon pools (above and below ground biomass, soil, dead wood and litter) were analyzed. A total of $51\left(400 \mathrm{~m}^{2}\right)$ sample plots were established using stratified-random sampling technique to estimate biomass across six vegetation classes in three landscape types (forest reserve, ranches and conservancies) using nested-plot design. Above ground biomass was determined using generalized multispecies model with diameter at breast height, height and wood density as variables. Below ground, soil, litter and dead wood biomass; carbon stocks and carbon dioxide equivalents $\left(\mathrm{CO}_{2 \mathrm{eq}}\right)$ were estimated using secondary information. The $\mathrm{CO}_{2 \mathrm{eq}}$ was multiplied by current prices of carbon trade to compute carbon sequestration value. Mean \pm SE of biomass and carbon was determined across vegetation and landscape types and mean differences tested by one-way Analysis of Variance. Mean biomass and carbon was about $79.15 \pm 40.22 \mathrm{~TB} \mathrm{ha}^{-1}$ and $37.25 \pm 18.89 \mathrm{TC}$ $\mathrm{ha}^{-1}$ respectively. Cumulative carbon stock was estimated at $682.08 \mathrm{TC} \mathrm{ha}^{-1}$; forest reserve (251.57 $\mathrm{TC} \mathrm{ha}^{-1}$ ) had significantly high levels of carbon stocks
\end{abstract}


compared to ranches $\left(209.78 \mathrm{TC} \mathrm{ha}^{-1}\right)$ and conservancies $\left(220.73 \mathrm{TC} \mathrm{ha}^{-1}, P\right.$ $=0.000)$. Further, closed forest significantly contributed to the overall biomass and carbon stock (58\%). The carbon sequestration potential was about $19.9 \mathrm{MTCO}_{2 \mathrm{eq}}$ with most conservative worth of KES 39.9B (US\$40M) per annum. The high carbon stock in the landscape shows the potential of dryland ecosystems as carbon sink for climate change mitigation. However, for communities to benefit from bio-carbon funds in future, sustainable landscape management and restorative measures should be practiced to enhance carbon storage and provision of other ecosystem services.

\section{Keywords}

Carbon Sequestration, Carbon Stock, Economic Value, Dryland

Forest-Landscape, Kenya

\section{Introduction}

The main carbon pools on earth systems are atmosphere, terrestrial biosphere, ocean and Earth's crust (Hoover \& Riddle, 2020). Terrestrial ecosystems (mainly forest, soil and wetland), are the major carbon pool components on earth's system (Beedlow et al., 2004; Lal et al., 2012; Xu et al., 2018) and largely contributes to the global carbon balance (IPCC, 2007; Hoover \& Riddle, 2020). However, anthropogenic activities such as land-use change and combustion of biomass and fossil fuel are largely contributing to de-carbonization and accumulation of bio-spheric greenhouse gases (GHGs) - (Lal et al., 2012; Ciais et al., 2014; Friedlingstein et al., 2019). The accumulation of carbon dioxide $\left(\mathrm{CO}_{2}\right)$ and other GHGs in the upper atmosphere, has led to climate variability and associated stochastic events such as increases in the average global temperature, drought and flood events (Lal, 2004; Dabasso et al., 2014).

Since pre-industrial times, global $\mathrm{CO}_{2}$ concentration in the atmosphere has increased by over $40 \%$ from about 277 parts per million (ppm) in 1750 to 407.38 $\pm 0.1 \mathrm{ppm}$ in 2018 (Joos and Spahni, 2008; IPCC, 2013; Dlugokencky and Tans, 2018). Accordingly, warming from pre-industrial levels to the decade 2006-2015 was estimated to be $0.87^{\circ} \mathrm{C}$ (IPCC, 2019) and reached approximately $1^{\circ} \mathrm{C}$ above pre-industrial levels in 2017 (Allen et al., 2018). International efforts aim to limit the temperature increase to below $2^{\circ} \mathrm{C}$, preferably $1.5^{\circ} \mathrm{C}$ above the pre-industrial level to reduce the risks and impacts of climate change (Gao et al., 2017; IPCC, 2018). According to the Nationally Determined Contribution synthesis report of 2021 , to limit global warming to below $2^{\circ} \mathrm{C}, \mathrm{CO}_{2}$ emissions need to decrease by about 25\% from 2010 level by 2030 and reach net zero around 2070 (Chevallier, 2021). Consequently, climate mitigation strategies not only focus on reducing emissions of GHGs into the atmosphere but more on removing and stabilizing carbon concentration in the atmosphere (Gren \& Aklilu, 2016).

Re-carbonization of the biosphere is important to reduce net anthropogenic 
carbon emissions through sequestration of $\mathrm{CO}_{2}$ (Lal et al., 2012). Carbon sequestration is an important ecosystem service provided largely by terrestrial ecosystems. Estimates suggest that terrestrial ecosystems release about 10 to $20 \%$ of the total global $\mathrm{CO}_{2}$ to the atmosphere due to land degradation, but also sequesters about $30 \%$ of $\mathrm{CO}_{2}$ emissions from anthropogenic activities (Gibbs et al., 2007; Harris et al., 2012; Houghton et al., 2012; Houghton \& Nassikas, 2018; Friedlingstein et al., 2019; IPCC, 2019). Accordingly, between 2009 and 2018, the terrestrial $\mathrm{CO}_{2}$ sink increased to about $3.2 \pm 0.7 \mathrm{GtC} \mathrm{yr}^{-1}$ down from $1.3 \pm 0.4$ GtC $\mathrm{yr}^{-1}$ in the 1960s (Friedlingstein et al., 2019). Despite the high potential of these ecosystems to sequester carbon, emissions from land-use changes and deforestation coupled with other carbon sources outweigh the carbon sink leading to the accumulation of greenhouse gases.

Forested landscapes are the largest carbon pool of the terrestrial ecosystem and integral in global carbon cycle (Pan et al., 2011; Abere et al., 2017; Zhao et al., 2019). The carbon pools in forest areas include; living biomass (above and below-ground biomass), dead organic matter (dead wood and litter) and soils (soil organic matter)_(Pan et al., 2011; Zhao et al., 2019; Hoover \& Riddle, 2020). According to Pan et al. (2011), the carbon stock in the world's forests is estimated to be $861 \pm 66 \mathrm{Pg} \mathrm{C}$, with about $383 \pm 30 \mathrm{Pg} \mathrm{C}(44 \%)$ in soil ( $1 \mathrm{~m}$ depth), $363 \pm 28 \mathrm{Pg} \mathrm{C}(42 \%)$ in live biomass, $73 \pm 6 \mathrm{Pg} \mathrm{C}(8 \%)$ in deadwood, and $43 \pm 3 \mathrm{Pg} \mathrm{C}(5 \%)$ in litter. Out of $861 \mathrm{Pg} \mathrm{C}$, about $471 \mathrm{Pg}(\sim 45 \%)$ of it is stored in tropical forests. The uptake of $\mathrm{CO}_{2}$ from the atmosphere and storage within the forested ecosystem is one of the most practical and feasible way of reducing present and future emissions of $\mathrm{CO}_{2}$ in the atmosphere (Trumper et al., 2008). It is also less costly since, it is natural based process and can be enhanced through restorative land-use and sustainable management (Lal et al., 2012).

Reducing carbon emissions is critical in combating climate change. Various carbon reduction mechanisms have been put in place by the United Nations Framework Convention on Climate Change (UNFCCC). These include Kyoto protocol, reducing emissions from deforestation and degradation (REDD+), the nationally determined contributions as provided for in the Paris agreement and the creation of carbon credit offset markets. Accordingly, International initiatives to offset and maintain greenhouse gases require an understanding of the existing and future potential of forest landscapes in carbon emissions and sequestration (Lal et al., 2012). Therefore, estimation of biomass (carbon stock) is pre-requisite to quantify the potential carbon sequestration in forests including the woodlands.

The estimates of biomass (and carbon) can be determined through field inventories only or a combination with various remote sensing approaches (Ubuy et al., 2018) using both direct and indirect methods. Direct methods use biomass models developed through destructive sampling of selected trees, while indirect methods involve the use of allometric volume equations, form factor and biomass expansion factors and or with wood basic density (Chave et al., 2014; Nja- 
na, 2017). The direct method although the most reliable and accurate approach, is time consuming and destructive (Vashum \& Jayakumar, 2012) and may not be applicable in protected or threatened forests (Tetemke et al., 2019). Therefore, the use of allometric models is the commonly used approach (Chave et al., 2003; Ngomanda et al., 2014). Conversely, the accuracy of biomass estimated using allometric models is dependent on the appropriateness and applicability of the chosen model (Chave et al., 2014). The models can be species specific (species-site specific, species specific but from multiple sites) or general (multiple species from single site or multi-species from several sites) -(Henry et al., 2011). The general multi species-site models are appropriate for extensive forested landscapes with large number of different species (Chave et al., 2005) as is the case in this study.

Drylands occupy about $45.4 \%$ to $47.2 \%$ of the world's total land area (Lal, 2004; Lal, 2019). The dryland ecosystem contributes significantly to land-based carbon sink and negative feedback to global carbon cycle given its expansiveness (Lal, 2019) and stores about one third of the global carbon stock (Trumper et al., 2008). The drylands of Kenya cover about $80 \%$ of the total landmass in the Country (Githae \& Mutiga, 2021). These drylands are mostly utilized for pastoral systems. The potential of rangelands and dryland forests to store carbon is well documented globally (Lal, 2004; IPCC, 2007; Trumper et al., 2008; Lal, 2019) and is influenced by its response to communal grazing effects (Perez-Quezada et al., 2011). However, the potential of these pastoral ecosystems to sequester and store carbon is poorly understood in Kenya. Moreover, attempts to estimate carbon stock in such ecosystems have not considered heterogeneity of these landscapes.

This study was undertaken in the heterogeneous pastoral environments of Mukogodo forest landscape, in the drylands of Northern Kenya. The objectives of the study were to assess the potential of Mukogodo forest landscape to store and sequester carbon, and equivalent economic value of carbon sequestration. The study covered the woodlands (ranches and conservancies) and dry forest (Mukogodo forest reserve). The study sites were classified into three landscape types (forest reserve, conservancy and ranch) and six vegetation categories (closed forest, open forest, grassland, shrubland, bare land and Opuntia dominated areas) depending on vegetation life forms and canopy cover to capture landscape variability in drylands of Northern Kenya. The study applied the commonly used tree variables (Diameter at Breast Height-DBH, total tree height and wood density) -(Chave et al., 2014) to estimate above ground biomass carbon and analyzed four main carbon pools of forest landscapes (living biomass, soil, deadwood and litter). The purpose of this study therefore, was to understand the capacity of dryland ecosystems to offset carbon and combat climate change by estimating the carbon stock and carbon sequestration potential and worth. The findings can contribute to the development of conservation policies for these fragile ecosystems as carbon sinks and for understanding the potential for carbon credits and associated economic benefits to the society in future. 


\section{Materials and Methods}

\subsection{Materials}

\section{Description of Study Area}

Mukogodo forest landscape is composed of forest reserve, group ranches and conservancies and traverses Laikipia and Isiolo Counties of Kenya. It lies approximately between longitude $37^{\circ} 05^{\prime} \mathrm{E}$ to $37^{\circ} 23^{\prime} \mathrm{E}$ and at latitude $0^{\circ} 18^{\prime} \mathrm{N}$ and $0^{\circ} 32 ' \mathrm{~N}$. In Laikipia County, the landscape encompasses the Mukogodo forest reserve (30,189 ha) and four surrounding group ranches namely; Ilngwesi (9470 ha) in the southeast, Makurian (5390 ha) in the southwest, Kurikuri (3340 ha) in the northwest and Lekuruki (15,872 ha) in the northeast of the forest (KIFCON, 1994; Kagombe et al., 2006; Kagombe and Owuor, 2007). The landscape also extends to two conservancies in Isiolo County (Oldonyiro 52,500 ha and Leparua 34,200 ha)-Figure 1.

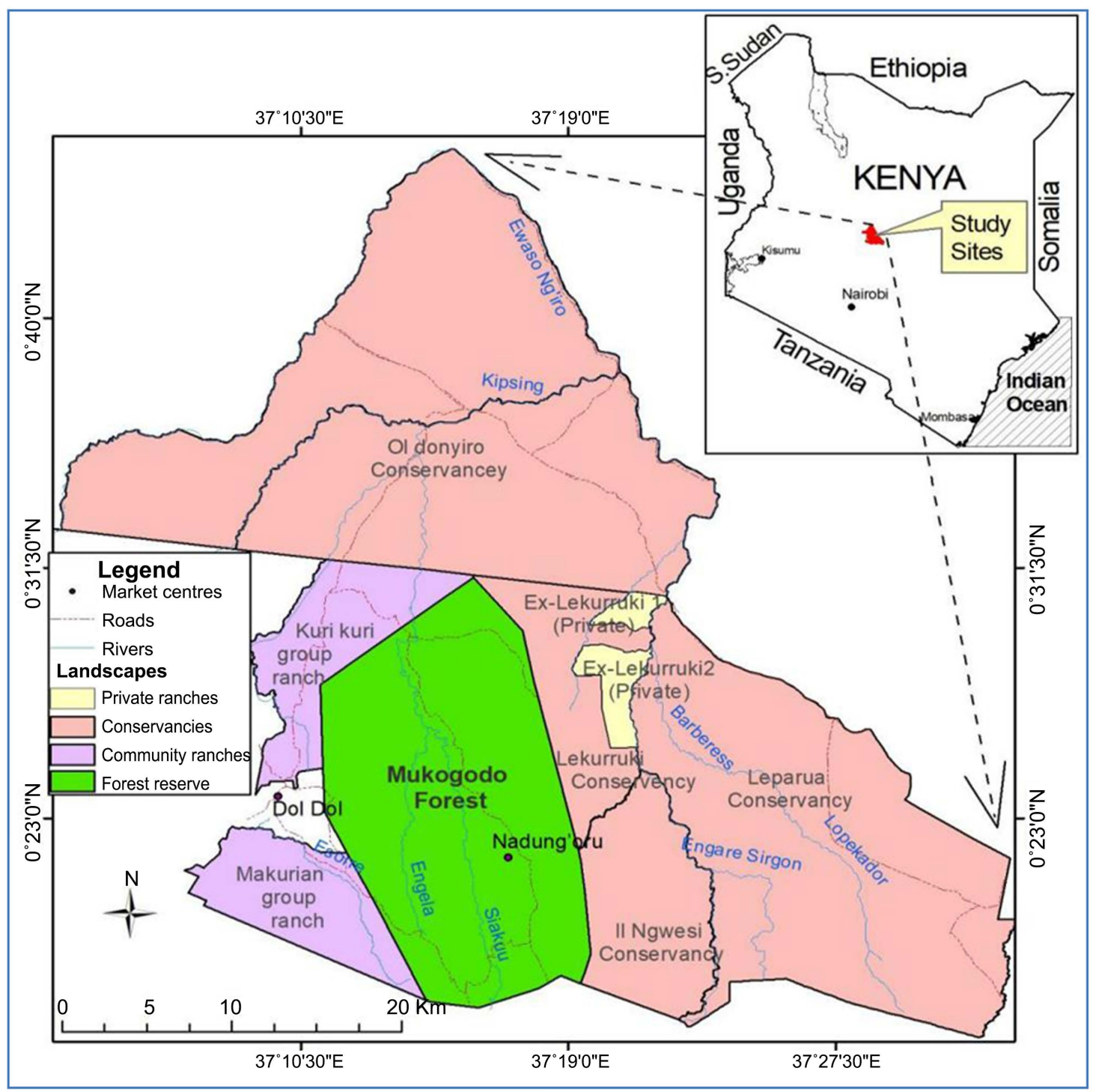

Figure 1. Map showing the location of Mukogodo forest landscape (Source: Authors). 
The landscape is found in agro-climatic zone V, (semi-arid), thus an ecologically sensitive ecosystem (World Bank, 1993; KFS, 2008). It is characterized by rugged terrains with hilly masses of between $10 \%$ and $40 \%$ slope (Muchiri and Gachathi, 2006; KFS, 2008). The elevation ranges between 1600 to $2100 \mathrm{~m}$. The mean annual rainfall ranges between 400 and $600 \mathrm{~mm}$. The rainfall distribution is bimodal with long rains in March-April and short rains in October-December. The daily temperatures range from $18^{\circ} \mathrm{C}$ to $29^{\circ} \mathrm{C}$. The landscape is drained by seasonal rivers, the main ones being Sieku and Kipsing (KFS, 2008).

Mukogodo landscape is characterized by seven broad vegetation types: Closed forest, closed woodland, open forest, open grassland, open scattered trees, very open scattered trees, and degraded grassland. The most abundant trees in the landscape are Olea europaea ssp. africana, Acacia tortilis and Juniperus procera (Muchiri and Gachathi, 2006; KFS, 2008). The forest landscape is a habitat for 209 species of birds, 11 small mammals, and 34 large mammal species. The large mammal species include Elephant (Loxodonta africana), Buffalo (Syncarus caffer), Lion (Panthera leo), Leopard (Panthera pardus) and endangered grevy's Zebra (Equus grevyi) (KFS, 2008).

The Mukogodo landscape is inhabited by the Laikipia Maasai and the indigenous hunter-gatherer community Yaaku. The two Isiolo conservancies are mainly occupied by Samburu and Turkana in Oldonyiro conservancy, Turkana, Somali, Borana, and Samburu in Leparua conservancy. The main economic activity in the landscape is semi-sedentary pastoralism where cattle, sheep, goats and camels are kept in communal grazing lands (Ng'ethe et al., 1997; M'mboroki et al., 2018). Eco-tourism and nature-based enterprises are emerging economic activities in the landscape. Despite the significant importance of the Mukogodo ecosystem to the communities' livelihoods, forests and lands are threatened by degradation. The driving factors of degradation include forest fires, deforestation, charcoal production, and grazing pressure, which have reduced forest cover over the years (Webala et al., 2006; M'mboroki et al., 2018). For instance, between 1984 and 2014, the forested landscape in Mukogodo reduced by 3071 ha (24\%)-(M'mboroki et al., 2018). This increases the pressure on existing landscape to provide vital ecosystem services such as carbon storage and sequestration.

\subsection{Methods}

\subsubsection{Sampling and Data Collection}

Primary data for estimating above ground biomass and carbon stock were collected through vegetation assessment in accordance with National forest inventory sampling framework (Hyvönen et al., 2016; Ndambiri et al., 2020). Multi-stage stratified random sampling technique was used to collect vegetation data. The landscape was first stratified into three types: forest reserve, group ranches and conservancies. In each of the landscape class, the vegetation was further divided into six classes/types: closed forest, open forest, grassland, shrubland, bare land and Opuntia dominated areas and area (ha) under each vegeta- 
tion type was estimated using GIS and remote sensing technologies (Figure 2).

The number of plots sampled in each landscape type was proportional to the area under each vegetation type. The field sampling plots were pre-determined by randomly selecting coordinates points from a list generated through GIS techniques along six transects parallel to each other. The selected points were then loaded in a hand held GPS. The GPS coordinates were used to locate the first corner of the plots whereby the other plot corners were laid in North-West direction. Nested plot design was applied in the vegetation assessment. The main plot measuring $400 \mathrm{~m}^{2}$ was used to assess trees and shrubs with $\mathrm{DBH} \geq 5 \mathrm{~cm}$. Sub-plot of $25 \mathrm{~m}^{2}$ was nested at the first corner of the main plot was used to assess woody regenerates $(\geq 1 \mathrm{~cm}$ but $<5 \mathrm{~cm} \mathrm{DBH})$. Within the plots, plants were identified to species level in local and botanical names with assistance from $\mathrm{Pa}$ ra-taxonomist and a Botanist. The $\mathrm{DBH}$ and height of regenerates and trees were measured at $1.3 \mathrm{~m}$ above ground using a diameter tape and Suunto clinometer respectively. A total of fifty one (51) sample plots were established and assessed across the six vegetation classes in the three landscapes types. Secondary data and

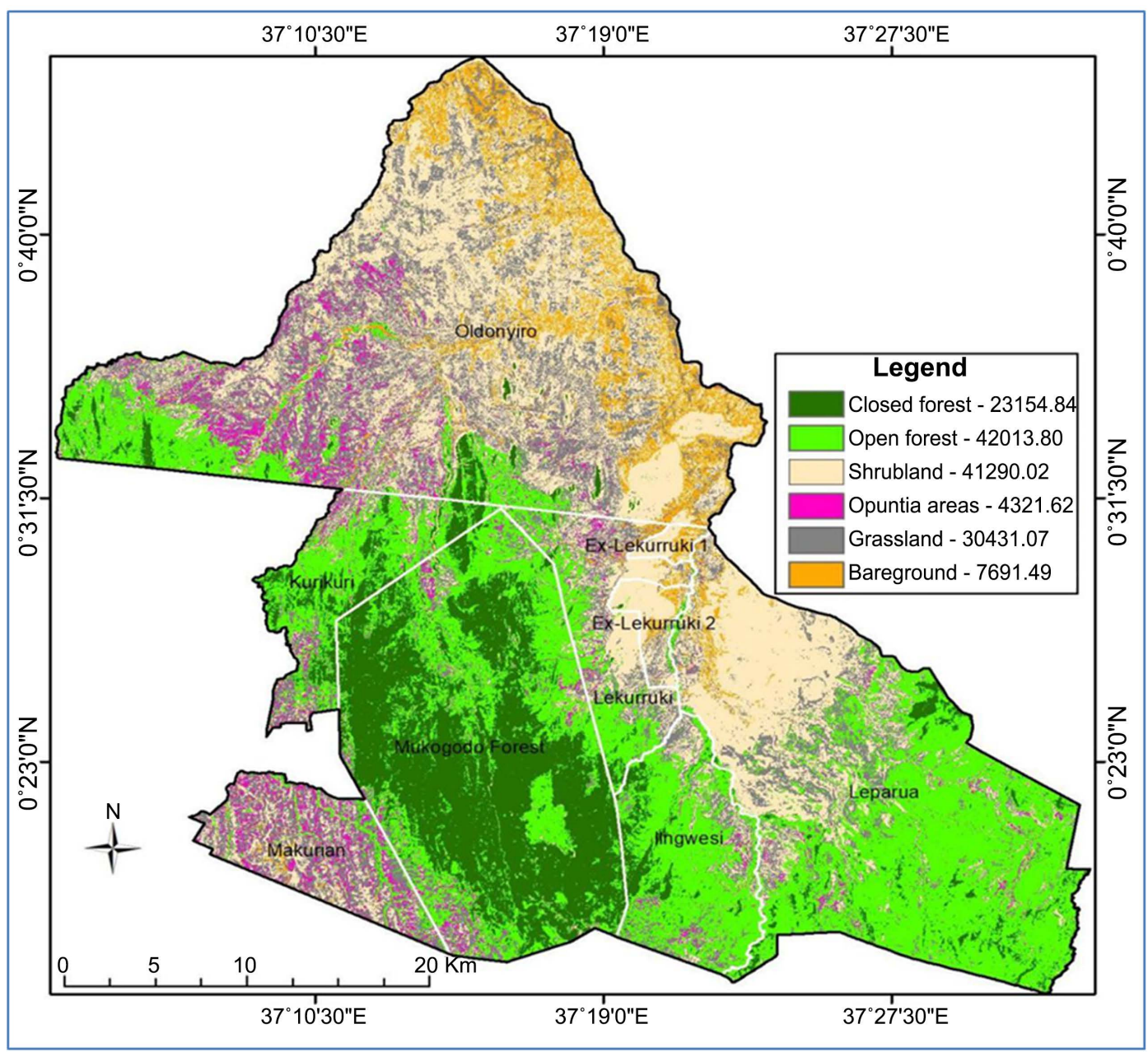

Figure 2. Map showing Mukogodo landscape vegetation types and respective area (Ha) (Source: Authors). 
information on wood density, productivity of Opuntia and models for estimating biomass were obtained from intensive review of literature from scientific articles with emphasis on biomass and carbon stock in dryland tropical montane forests and range lands.

\subsubsection{Data Processing and Analysis}

Four main carbon pools were identified for estimation of the total carbon stock in the landscape: living biomass (Above Ground Biomass-(AGB) and Below Ground Biomass-(BGB), soil, litter and dead wood (MacDicken, 1997; Marklund and Schoene, 2006; Pan et al., 2011). First, AGB of trees was determined using generalized multispecies linear allometric equation for tropical dryland forest of Ethiopia (Tetemke et al., 2019) as described in Equation (1).

$$
Y=0.327 d^{2.016} h^{0.055} \rho^{0.505} \text {. }
$$

where $Y$ is AGB $(\mathrm{kg} / \mathrm{ha}), d$ is Diameter at Breast Height $(\mathrm{cm}), h$ is the total tree height $(\mathrm{m})$ while $\rho$ is the wood density $\left(\mathrm{g} \cdot \mathrm{cm}^{-3}\right)$.

The above equation was selected due similarity in species harvested to develop the model with those sampled in this study and the similarity in eco-climatic conditions with Mukogodo landscape. Moreover, the model applied more than one parameter (DBH, height and wood density) which tend to give reliable results (Chave et al., 2005; Nam et al., 2016; Aabeyir et al., 2020).

Secondly, BGB was estimated as a fraction of the above ground biomass by multiplying with a shoot root ratio of 0.28 (MEF, 2019) and comparing with values from other studies (Cairns et al., 1997; MacDicken, 1997; IPCC, 2003; Marklund \& Schoene, 2006; Mokany et al., 2006). Dead wood biomass was estimated based on dead-live ratios of 0.12 (Marklund \& Schoene, 2006). Litter biomass was assumed to be $5 \%$ of the total biomass (Marklund \& Schoene, 2006; Pan et al., 2011; Sun and Liu, 2020). The soil carbon was assumed to account for $32 \%$ of the biomass (Pan et al., 2011) based on assumption that both AGB and BGB account for $56 \%$ of the total carbon pool (Pan et al., 2011). The total biomass of Opuntia stricta was assumed to be $63.52 \mathrm{~TB} \mathrm{ha}^{-1}$ based on proxy of mean productivity of Opuntia ficus-indica found in several studies (Nobel, 1995; Nefzaoui et al., 2014; Dubeux Jr. et al., 2015; Fouche \& Coetzer, 2015; Iqbal et al., 2020). Respective carbon stock in each carbon pool was estimated by multiplying biomass by a coefficient of 0.475 (Raghubanshi, 1991; Singh and Chand, 2012). This study assumed that soil carbon accounted for $100 \%$ of total carbon stocks for bare land in accordance with Solomon et al. (2018). Accordingly, the carbon stock of bare land was assumed to be the average of grassland and shrubland soil carbon, since most bare lands in the landscape are within the two vegetation types.

The mean \pm SE of biomass and carbon stock was determined for each carbon pool, landscape category and vegetation type. Mean total biomass and carbon were estimated by multiplying the mean carbon per vegetation type and respective area. To estimate carbon sequestration capacity, carbon dioxide equivalent 
$\left(\mathrm{CO}_{2 \mathrm{eq}}\right)$ was calculated by multiplying the total carbon stock by a factor of 3.67 (Petersson et al., 2012). The $\mathrm{CO}_{2 \mathrm{eq}}$ was then multiplied by the current prices of carbon trade to obtain potential carbon sequestration economic value as per Equation (2):

$$
V_{C}=E_{\mathrm{CO}_{2} \mathrm{eq}} \rho
$$

where $V c$ is the value of carbon sequestration (US\$), $E_{\mathrm{CO} 2 \mathrm{q}}$ is the estimated carbon dioxide equivalent, while $\rho$ is the price of carbon (US\$).

According to the World Bank (2020), Carbon prices ranged from less than US $\$ 1 \mathrm{~T}^{-1} \mathrm{CO}_{2 \mathrm{eq}}$ to US $\$ 119 \mathrm{~T}^{-1} \mathrm{CO}_{2 \mathrm{eq}}$, with almost half of the covered emissions priced at less than US $\$ 10 \mathrm{~T}^{-1} \mathrm{CO}_{2 \mathrm{eq}}$. This study used a conservative value of 2 US $\$ \mathrm{~T}^{-1} \mathrm{CO}_{2 \mathrm{eq}}$, the global average carbon price provided by $\operatorname{IMF}(2019)$-to demonstrate the lowest case scenario, a mean of $20.46 \mathrm{US}^{\mathrm{T}} \mathrm{T}^{-1} \mathrm{CO}_{2 \mathrm{eq}}$ to show moderate scenario adopted from IHS Markit's Global Carbon Index 2020, which is made up of prices from the California Compliance Allowance, Regional Greenhouse Gas Initiative (RGGI), and European Allowance prices, with the weighted global price on carbon equivalent of US $\$ 20.81 \mathrm{~T}^{-1} \mathrm{CO}_{2 \mathrm{eq}}$ and the World Bank's data with a similar price across its 61 jurisdictions at US\$20.11 T $\mathrm{T}^{-1} \mathrm{CO}_{2 \mathrm{eq}}$ (Carbon Credit Capital, 2020). The highest case scenario used a price of 80 US $\$ \mathrm{~T}^{-1} \mathrm{CO}_{2 \mathrm{eq}}$ as suggested by the high-level commission on carbon prices estimated that carbon prices of at least US $\$ 40-80 \mathrm{~T}^{-1} \mathrm{CO}_{2 \mathrm{eq}}$ by 2020 are required to cost-effectively reduce emissions in line with the temperature goals of the Paris Agreement (World Bank, 2020).

One way Analysis of Variance (ANOVA) was used to test the differences in biomass and carbon stocks across the carbon pools, landscape categories (forest reserve, community ranches and conservancies) and among the six vegetation types using MINITAB version 19.1.1.0 at 95\% confidence level. The means with significant differences were separated by Tukey's honestly significant difference post hoc test.

\section{Results}

\subsection{Biomass and Carbon Stocks}

The mean biomass both (living and dead) in the landscape was about $79.15 \pm$ 40.22 $\mathrm{TB} \mathrm{ha}^{-1}$ while the mean carbon was found to be $37.25 \pm 18.89 \mathrm{TC} \mathrm{ha}^{-1}$. The disaggregation of the above carbon stocks for various carbon pools indicates that $56.15 \%$ was stored in both above and below ground biomass, $32.09 \%$ was stored in the soils, $6.74 \%$ in the dead wood and $5.02 \%$ in the litter. Significant variation existed in mean biomass and carbon stocks across the different carbon pools $\left(\mathrm{DF}_{3,200}=18.95, P=0.000\right)$-Table 1 . The closed forest contributed the most to all the carbon pools compared to the other vegetation categories. The contribution of (Opuntia vs. open forest) and (shrubland vs. grassland) was comparable. The bare land contributed marginally to the carbon pools through soil carbon pool only (Figure 3). 
Table 1. Overall biomass and carbon stocks in Mukogodo forest landscape.

\begin{tabular}{ccc}
\hline Carbon pool & Mean biomass $\left(\mathrm{T} \mathrm{ha}^{-1}\right)$ & Mean carbon $\left(\mathrm{T} \mathrm{ha}^{-1}\right)$ \\
\hline Below and above ground & $47.12^{\mathrm{a}} \pm 8.03$ & $22.15^{\mathrm{a}} \pm 3.77$ \\
Soil & $26.93^{\mathrm{b}} \pm 4.59$ & $12.66^{\mathrm{b}} \pm 2.16$ \\
Dead wood & $5.65^{\mathrm{c}} \pm 0.97$ & $2.66^{\mathrm{c}} \pm 2.16$ \\
Litter & $4.21^{\mathrm{d}} \pm 0.72$ & $1.98^{\mathrm{d}} \pm 0.34$ \\
\hline Landscape type & Mean biomass $\left(\mathrm{T} \mathrm{ha}^{-1}\right)$ & Mean carbon $\left(\mathrm{T} \mathrm{ha}^{-1}\right)$ \\
\hline Mukogodo forest reserve & $209.00^{\mathrm{a}} \pm 31.00$ & $98.20^{\mathrm{a}} \pm 14.60$ \\
Laikipia group ranches & $13.17^{\mathrm{b}} \pm 4.38$ & $6.19^{\mathrm{b}} \pm 2.06$ \\
Isiolo conservancies & $26.50^{\mathrm{b}} \pm 4.94$ & $12.46^{\mathrm{b}} \pm 2.32$ \\
\hline Vegetation type & Mean biomass $\left(\mathrm{T} \mathrm{ha}^{-1}\right)$ & Mean carbon $\left(\mathrm{T} \mathrm{ha}^{-1}\right)$ \\
\hline Closed & $273.82^{\mathrm{a}} \pm 30.50$ & $128.70^{\mathrm{a}} \pm 14.30$ \\
Open & $72.92^{\mathrm{b}} \pm 19.50$ & $34.27^{\mathrm{b}} \pm 9.15$ \\
Shrubland & $23.7^{\mathrm{b}} \pm 3.75$ & $11.14^{\mathrm{b}} \pm 1.76$ \\
Grassland & $32.43^{\mathrm{b}} \pm 16.70$ & $15.24^{\mathrm{b}} \pm 7.86$ \\
Opuntia & 63.52 & 30.17 \\
Bare land & 8.49 & 3.99 \\
\hline Men & &
\end{tabular}

Note: Means with different superscript letters are significantly different at $95 \%$ confidence level. Also, Opuntia dominated areas and bare land does not contain error bars of means because their total carbon pools estimates were derived from secondary data.

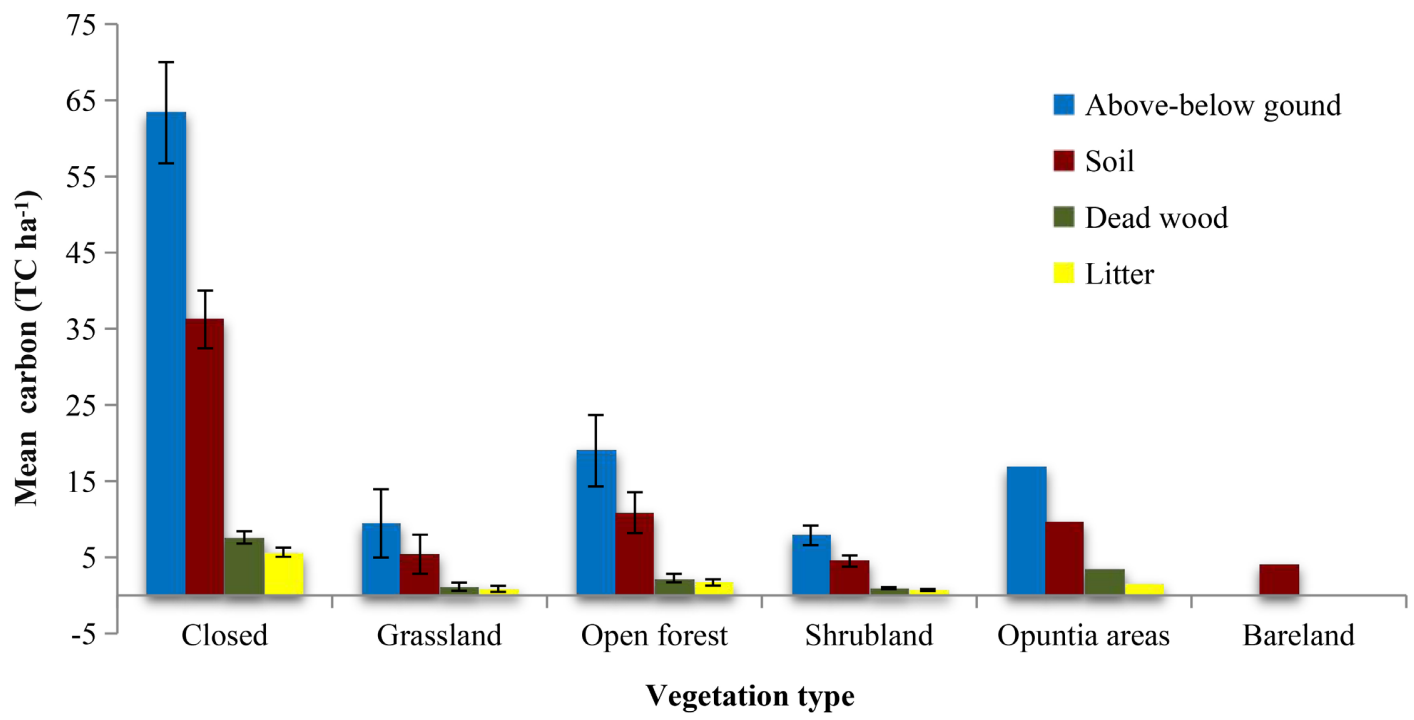

Figure 3. Carbon pools across the vegetation types in Mukogodo forest landscape. Note: Opuntia dominated areas and bare land does not contain error bars of means because their total carbon pools estimates were derived from secondary data.

Generally, the forest reserve had significantly high quantities $(\sim 84 \%)$ of the total biomass and carbon stocks $\left(209.00 \pm 31.00 \mathrm{~TB} \mathrm{ha}^{-1}\right.$ and $98.20 \pm 14.60 \mathrm{TC}$ $\mathrm{ha}^{-1}$ respectively) compared to the group ranches and conservancies $\left(\mathrm{DF}_{2,48}=\right.$ 
$31.69, P=0.000)$. Although not significant, the group ranches showed less capacity of carbon storage by $50.31 \%$ compared to the conservancies. Further, the closed forest areas significantly contributed to the overall biomass and carbon stock $\left(273.82 \pm 30.50 \mathrm{~TB} \mathrm{ha}{ }^{-1}\right.$ and $128.70 \pm 14.30 \mathrm{TC} \mathrm{ha}^{-1}$ respectively) in the Mukogodo forest landscape in relation to the other vegetation types by about $58 \%\left(\mathrm{DF}_{5,45}=51.83, P=0.000\right)$. Notably, the conversion of intact forest to open forest has the potential carbon loss of about $73.37 \%$. As expected, the bare land had the least capacity of carbon storage with about $3.99 \mathrm{TC} \mathrm{ha}^{-1}$. Opuntia dominated sites showed high capacity to store carbon than grasslands and shrubland by $49.95 \%$ and $62.69 \%$ respectively (Table 1 ). However, being an invasive species, it is associated with negative effect on the ecosystem functionality.

The mean total biomass and carbon storage was estimated at 14,449 $\mathrm{TB} \mathrm{ha}^{-1}$ and $682.08 \mathrm{TC} \mathrm{ha}^{-1}$ respectively (Table 3 ). Of this carbon stock quantities, $251.57 \mathrm{TC} \mathrm{ha}^{-1}$ were stored in the forest reserve while, 209.78 and $220.73 \mathrm{TC} \mathrm{ha}^{-1}$ were stored in the group ranches and conservancies respectively (Table 2). The total biomass and carbon stock in Mukogodo forest landscape were estimated at 11,552,768.98 TB and 5,431,309.0 TC respectively (Annex).

\subsection{The Value of Carbon Sequestration}

The carbon sequestration potential in the landscape was about 19,932,905.70 $\mathrm{T}$ $\mathrm{CO}_{2 \text { eq }}$ per year worth between US $\$ 39,865,811.39$ and $1,594,632,455.78$ annually or (US $\$ 260.37$ and $10,414.97 \mathrm{ha}^{-1}$ year $^{-1}$ respectively). The most conservative estimate of carbon sequestration worth for the landscape was KES 3.99 billion with KES 2.0 billion, 670 million and 1.4 billion for Mukogodo forest reserve, group ranches and community conservancies respectively (Table 3 ). The forest reserve contributed nearly half (49.30\%) of the total carbon sequestration value, hence underpins the need for its conservation. The ranches and conservancies contributed about $16.92 \%$ and $33.78 \%$ respectively.

Table 2. Biomass and carbon stock across the landscape and vegetation types in Mukogodo.

\begin{tabular}{ccc}
\hline \multicolumn{3}{c}{ Landscape type vs vegetation type biomass and carbon stocks } \\
\hline Mukogodo forest reserve & Mean biomass $\left(\mathrm{TB} \mathrm{ha}^{-1}\right)$ & Mean carbon $\left(\mathrm{TC} \mathrm{ha}^{-1}\right)$ \\
\hline Closed forest & 273.82 & 128.70 \\
Open & 72.92 & 34.27 \\
Grassland & 92.13 & 43.30 \\
Shrubland & 23.70 & 11.14 \\
Opuntia & 63.52 & 30.17 \\
Bare land & 8.49 & 3.99 \\
Total & 534.58 & 251.57 \\
\hline Laikipia group ranches & & 5.66 \\
\hline Shrubland & 12.05 & \\
\hline
\end{tabular}




\begin{tabular}{ccc} 
Continued & & \\
\hline Grassland & 14.87 & 6.99 \\
Closed forest & 273.82 & 128.70 \\
Open & 72.92 & 34.27 \\
Opuntia & 63.52 & 30.17 \\
Bare land & 8.49 & 3.99 \\
Total & 445.67 & 209.78 \\
\hline Isiolo conservancies & & 12.97 \\
\hline Shrubland & 27.59 & 10.63 \\
Grassland & 22.61 & 128.70 \\
Closed forest & 273.82 & 34.27 \\
Open & 72.92 & 30.17 \\
Opuntia & 63.52 & 3.99 \\
Bare land & 8.49 & 220.73 \\
Total & 468.95 & 682.08 \\
Grand total & 1449.20 & \\
\hline & & \\
\hline & & \\
\hline
\end{tabular}

Table 3. Carbon sequestration potential and worth in Mukogodo forest landscape.

\begin{tabular}{|c|c|c|c|c|c|c|c|}
\hline \multirow[t]{2}{*}{ Category } & \multirow{2}{*}{$\begin{array}{l}\text { a) Carbon } \\
\left(\mathrm{TC} \mathrm{ha}^{-1}\right)\end{array}$} & \multirow{2}{*}{$\begin{array}{l}\text { b) Total } \\
\text { area (ha) }\end{array}$} & $\begin{array}{c}\text { c) Total } \\
\text { Carbon (T) }\end{array}$ & d) $\mathrm{CO}_{2 \mathrm{eq}}(\mathrm{T})$ & $\begin{array}{c}\text { e) Lowest } \\
\text { value (US\$) }\end{array}$ & $\begin{array}{l}\text { f) Moderate } \\
\text { value (US\$) }\end{array}$ & $\begin{array}{l}\text { g) Highest } \\
\text { value (US\$) }\end{array}$ \\
\hline & & & $=a^{x} b$ & $=c^{x} 3.67$ & $=d^{d} 2$ US\$ & $=d^{x} 20.46$ US\$ & $=d^{x} 80$ US $\$$ \\
\hline Forest reserve & 251.57 & $29,537.80$ & $2,677,641.45$ & $9,826,944.14$ & $19,653,888.28$ & $201,059,277.06$ & $786,155,531.01$ \\
\hline Group ranches & 209.78 & $31,964.40$ & $918,727.73$ & $3,371,730.78$ & $6,743,461.57$ & $68,985,611.81$ & $269,738,462.61$ \\
\hline Conservancies & 220.73 & $91,607.40$ & $1,834,940.27$ & $6,734,230.78$ & $13,468,461.55$ & $137,782,361.70$ & $538,738,462.16$ \\
\hline Total & 682.08 & $153,109.60$ & $5,431,309.45$ & $19,932,905.70$ & $39,865,811.39$ & $407,827,250.57$ & $1,594,632,455.78$ \\
\hline
\end{tabular}

\section{Discussion}

\section{Biomass, Carbon Stock and Carbon Financing}

International efforts are in place to stabilize GHGs emissions and climate such as the Kyoto protocol, compliance and voluntary carbon trading markets, clean development mechanisms (REDD+) and the nationally determined contribution. According to the United Nations Framework Convention on Climate Change (UNFCCC) Bali conference in 2007, resolutions were made regarding strategies to combat climate change by the ratified countries. They include; developed countries should adopt national emission reduction targets and provide developing countries with mitigation financing and capacity building; while developing countries should undertake mitigation actions (Carpenter, 2008). Further, the Paris agreement in 2015 reaffirmed that developed countries should take the lead in providing financial assistance to party countries that are less endowed and more vulnerable, and commitment of voluntary contributions by all ratified 
countries (Gao et al., 2017). By 2020, party countries were to submit their plans for climate action-the nationally determined contributions (NDCs). Kenya committed to abate GHGs emissions by $32 \%$ by 2030 relative to the business as usual scenario of $143 \mathrm{MTCO}_{2 \mathrm{eq}}(\mathrm{MEF}, 2021)$. The total emission reduction potential for the country is about $86 \mathrm{MTCO}_{2 \mathrm{eq}}$. The remaining $40 \mathrm{MTCO}_{2 \mathrm{eq}}$ is secured for carbon credits/trading. Out of $86 \mathrm{MTCO}_{2 \mathrm{eq}}$, forestry is expected to meet about $24 \%\left(20.8 \mathrm{MTCO}_{2 \mathrm{eq}}\right)$ of the total emissions. This underscores the need for reliable estimates of carbon sequestration potential of forested landscapes in the country. In this study, Mukogodo forest alone in the current state has the potential to sequester about $19 \mathrm{MTCO}_{2 \mathrm{eq}}$ without consideration of carbon emission through land use change and degradation. Sustainable management and implementation of carbon reduction interventions in Mukogodo landscape have the potential to sequester carbon worth about US\$40M annually through carbon trading.

To effectively participate in carbon market, reliable estimation of total biomass carbon storage is essential (Weiskittel et al., 2015). The robust estimate is also critical for sustainable forest management decision making, for monitoring status of the forest and reporting carbon stock dynamics as required by Reducing Emissions from Deforestation and Forest Degradation (REDD+) mechanism (Ubuy et al., 2018). Further, the international negotiations on offsetting greenhouse gases require reliable current and potential estimates of forested areas to emit and sequester carbon (Pan et al., 2011). Therefore, valuing of the forest areas for their carbon storage potential may influence their protection through development of financial incentives for carbon storage.

Results from the study, indicate that, most of the carbon pools were contributed by living biomass carbon $(\sim 56 \%)$, followed by soil $(\sim 32 \%)$, deadwood and litter carbon by about $7 \%$ and $5 \%$ respectively. The litter and deadwood carbon were within the range reported by other studies (Tiessen et al., 1998; Pan et al., 2011). The high contribution of living biomass over soil to overall carbon were in agreement with Meena et al. (2019) who reported that living plant biomass contribute about $40 \%$ to $49 \%$ and Simegn et al., 2014 who reported about $57 \%$ of the total carbon from living biomass. Abere et al. (2017) and Atsbha et al. (2019) also reported findings that were within the range found in the study. This was, however contrary to the findings by other studies undertaken in nearly similar dry ecosystems (Dabasso et al., 2014; Solomon et al., 2018; Gebeyehu et al., 2019) who found soil to contribute the greatest carbon storage potential than the other carbon pools.

The variation in soil and living biomass carbon stock may have risen from the use of different biomass model, the application of empirical vs. secondary data and information in estimating carbon pools and methodological difference. Further, Zhao et al. (2019) indicated that the variation in data sources, estimation methods, scope of study area and environmental variables with different biotic and abiotic conditions and response to climate change may lead to significant variation in carbon storage estimates. Moreover, Keiluweit et al. (2015) re- 
ported that livestock grazing affect soil physico-chemical properties and nutrient cycling which result to soil organic carbon loss. The persistent grazing in $\mathrm{Mu}-$ kogodo forest landscape may have affected carbon storage potential of the soil carbon pool. The fact that majority of the carbon stock is stored in the living biomass suggests that any anthropogenic disturbances that might adversely affect the vegetation will have significant implication on carbon stock and sequestration potential of Mukogodo forest landscape.

The mean carbon stock from this study was slightly lower compared to those reported for nearly similar landscape in northern Kenya and Ethiopia (Dabasso et al., 2014; Gebeyehu et al., 2019), but was within the reported range in other dry forest-landscapes (Tiessen et al., 1998; Glenday, 2008; Simegn et al., 2014; Abere et al., 2017; Atsbha et al., 2019; Srinivas and Sundarapandian, 2019). The effects of vegetation and landscape type were significant on carbon stocks. The forest reserve stored most carbon within the landscape than the group ranches and conservancies. Furthermore, the high biomass carbon stock in closed forest than other vegetation types is in agreement with the findings of other studies in nearly similar ecosystems (Rajput et al., 2017; Solomon et al., 2017). In this study, the conversion of intact forest to open forest showed the potential carbon loss of about 73.37\%, which is within the range reported by Wekesa et al. (2016). The observed variation in biomass carbon across the landscape and vegetation types may be due to variation in tree density, height, diameter size and low litter which facilitate decomposition of plant material for soil carbon formation. The large diameter, heights and density of trees in the forest reserve may have contributed to high carbon stock (Gibbs et al., 2007; Solomon et al., 2017; Dibaba et al., 2019; Srinivas and Sundarapandian, 2019) and their removal will impact largely on biomass dynamics in the landscape. The slightly high potential of conservancies to store carbon compared to the ranches is an indication that unsuitable land use practices such as intensive grazing have high potential of enhancing carbon emission and reducing the capacity of rangelands as carbon sink.

Sustainable management of forest areas and rehabilitation can enhance carbon stock. According to Mendelsohn et al. (2012), about $42 \%$ of carbon storage could be achieved through reduced deforestation, 3\% from forest management, and estimated $27 \%$ from afforestation. Contrary, poor management coupled with deforestation and degradation can significantly reduce carbon storage (Dibaba et al., 2019). The existence of high carbon stock in the forest shows the potential of the area for climate change mitigation. The landscape should therefore be sustainably managed through reduction of deforestation and land degradation, promotion of sustainable landscape management to enhance in-situ carbon storage and carbon sequestration potential to mitigate effects of climate change and ensure continued provision of other ecosystem services.

\section{Conclusion and Recommendation}

\subsection{Conclusion}

This study estimated the biomass, total carbon stock, carbon sequestration po- 
tential and equivalent carbon storage economic value of Mukogodo forest landscape in drylands of Northern Kenya. The study approach accounted for the spatial and landscape-vegetation heterogeneity. The findings indicated that mean biomass both (living and dead) in Mukogodo forest landscape was about $79.15 \pm 40.22 \mathrm{~TB} \mathrm{ha}^{-1}$ with carbon storage potential of $37.25 \pm 18.89 \mathrm{TC} \mathrm{ha}^{-1}$. The mean total biomass and carbon storage for the landscape was estimated at 14,449 $\mathrm{TB} \mathrm{ha} \mathrm{h}^{-1}$ and $682.08 \mathrm{TC} \mathrm{ha}^{-1}$ respectively. Of these carbon stock quantities, forest reserve (251.57 TC ha ${ }^{-1}$ ) contributed significantly to the total carbon stock compared to 209.78 and $220.73 \mathrm{TC} \mathrm{ha}^{-1}$ from the group ranches and conservancies respectively. Furthermore, living biomass $(\sim 56 \%)$ and closed forest significantly (58\%) contributed to the overall biomass carbon stock in the landscape compared to the other vegetation types. The carbon sequestration potential in the landscape was about 19,932,905.70 $\mathrm{CO}_{2 \text { eq }}$ per year worth between US $\$ 39,865,811.39$ and $1,594,632,455.78$ year $^{-1}$ or (260.37 and 10,414.97 US $\$$ ha $^{-1}$ year $^{-1}$ respectively). The high carbon storage potential underscores the importance of the landscape as carbon sink and contribution to the global carbon cycle. Further, the large proportion of carbon in the landscape is stored in living biomass and closed forest, thus, a slight disturbance through deforestation and land use change may significantly reduce the carbon storage potential. The persistent exposure of group ranches to grazing had reduced their carbon storage potential by about $50.31 \%$ compared to the conservancies. The finding of this study will inform policy formulation on access of carbon funds through Clean Development and REDD+ mechanisms which will boost conservation and further enhance the carbon stocks.

\subsection{Recommendation}

Efforts should be enhanced to sustainably manage the landscape through restoration practices to reduce emissions associated with degradation and enhance carbon storage potential and flow of other ecosystem services. Continuous monitoring of carbon stock is also important to estimate net carbon storage and sequestration. To achieve this, the use of primary data in estimating carbon storage is highly recommended to give precise results. More research would be necessary to assess the impact of land use on carbon storage potential and feasibility of carbon credit investment in such pastoral ecosystems.

\section{Acknowledgements}

This study was funded by FAO through the GEF- 6 project on the Restoration of arid and semi-arid lands (ASALs) of Kenya through bio-enterprise development and other incentives under The Restoration Initiative being implemented by Kenya Forestry Research Institute. The authors also thank the field crew for their logistical and technical support that made data collection possible. Particularly, Mr. Rambei for his experience in plant identification and teams from the following organizations in Isiolo and Mukogodo: Kenya Forest Service; the 
Ilngwesi, Makurian, Mukogodo and Sieku Community Forest Association (ILLMAMUSI CFA); Leparua conservancy; community scouts and Interior coordination (Chiefs). We cannot mention all of you by the names, but your support is highly appreciated.

\section{Conflicts of Interest}

The authors declare that they have no competing interests with regard to the publication of this paper.

\section{References}

Aabeyir, R., Adu-Bredu, S., Agyare, W. A., \& Weir, M. J. (2020). Allometric Models for Estimating Aboveground Biomass in the Tropical Woodlands of Ghana, West Africa. Forest Ecosystems, 7, 1-23. https://doi.org/10.1186/s40663-020-00250-3

Abere, F., Belete, Y., Kefalew, A., \& Soromessa, T. (2017). Carbon Stock of Banja Forest in Banja District, Amhara Region, Ethiopia: An Implication for Climate Change Mitigation. Journal of Sustainable Forestry, 36, 604-622. https://doi.org/10.1080/10549811.2017.1332646

Allen, M. R., Dube, O. P., Solecki, W., Aragón-Durand, F., Cramer, W., Humphreys, S. et al. (2018). Framing and Context in Global Warming of $1.5^{\circ} \mathrm{C}$. In V. Masson-Delmotte, P. Zhai, H. O. Pörtner, D. Roberts, J. Skea, P. R. Shukla et al. (Eds.), An IPCC Special Report on the Impacts of Global Warming of $1.5^{\circ} \mathrm{C}$ above Pre-Industrial Levels and Related Global Greenhouse Gas Emission Pathways, in the Context of Strengthening the Global Response to the Threat of Climate Change, Sustainable Development, and Efforts to Eradicate Poverty (pp. 41-91). (In Press)

Atsbha, T., Desta, A. B., \& Zewdu, T. (2019). Carbon Sequestration Potential of Natural Vegetation under Grazing Influence in Southern Tigray, Ethiopia: Implication for Climate Change Mitigation. Heliyon, 5, e02329.

https://doi.org/10.1016/j.heliyon.2019.e02329

Beedlow, P. A., Tingey, D. T., Phillips, D. L., Hogsett, W. E., \& Olszyk, D. M. (2004). Rising Atmospheric $\mathrm{CO}_{2}$ and Carbon Sequestration in Forests. Frontiers in Ecology and the Environment, 2, 315-322. https://doi.org/10.1890/1540-9295(2004)002[0315:RACACS]2.0.CO;2

Cairns, M. A., Brown, S., Helmer, E. H., \& Baumgardner, G. A. (1997). Root Biomass Allocation in the World's Upland Forests. Oecologia, 111, 1-11.

https://doi.org/10.1007/s004420050201

Carbon Credit Capital (2020). The Value of Carbon Market Update 2020.

Carpenter, C. (2008). The Bali Action Plan: Key Issues in the Climate Negotiations. Summary for Policy Makers. An Environment and Energy Group Publication, UNDP.

Chave, J., Andalo, C., Brown, S., Cairns, M. A., Chambers, J. Q., Eamus, D., Yamakura, T. et al. (2005). Tree Allometry and Improved Estimation of Carbon Stocks and Balance in Tropical Forests. Oecologia, 145, 87-99. https://doi.org/10.1007/s00442-005-0100-x

Chave, J., Condit, R., Lao, S., Caspersen, J. P., Foster, R. B., \& Hubbell, S. P. (2003). Spatial and Temporal Variation of Biomass in a Tropical Forest: Results from a Large Census Plot in Panama. Journal of Ecology, 91, 240-252.

https://doi.org/10.1046/j.1365-2745.2003.00757.x

Chave, J., Réjou-Méchain, M., Búrquez, A., Chidumayo, E., Colgan, M. S., Delitti, W. B. et al. (2014). Improved Allometric Models to Estimate the Aboveground Biomass of 
Tropical Trees. Global Change Biology, 20,3177-3190.

https://doi.org/10.1111/gcb.12629

Chevallier, R. (2021). The Urgent Race to Net Zero: Exploring African Priorities for COP 26.

https://www.africaportal.org/publications/urgent-race-net-zero-exploring-african-prio rities-cop-26

Ciais, P., Sabine, C., Bala, G., Bopp, L., Brovkin, V., Canadell, J. et al. (2014). Carbon and Other Biogeochemical Cycles Supplementary Material. In T. F. Stocker, D. Qin, G. K. Plattner, M. Tignor, S. K. Allen, J. Boschung et al. (Eds.), Climate Change 2013: The Physical Science Basis. Contribution of Working Group I to the Fifth Assessment Report of the Intergovernmental Panel on Climate Change (pp. 465-570). Cambridge University Press.

Dabasso, B. H., Taddese, Z., \& Hoag, D. (2014). Carbon Stocks in Semi-Arid Pastoral Ecosystems of Northern Kenya. Pastoralism, 4, 1-8.

https://doi.org/10.1186/2041-7136-4-5

Dibaba, A., Soromessa, T., \& Workineh, B. (2019). Carbon Stock of the Various Carbon Pools in Gerba-Dima Moist Afromontane Forest, South-Western Ethiopia. Carbon Balance and Management, 14, Article No. 1. https://doi.org/10.1186/s13021-019-0116-x

Dlugokencky, E., \& Tans, P. (2018). Trends in Atmospheric Carbon Dioxide, National Oceanic \& Atmospheric Administration, Earth System Research Laboratory (NOAA/ESRL). http://www.esrl.noaa.gov/gmd/ccgg/trends/global.html

Dubeux Jr., J. C. B., dos Santos, M. V. F., de Mello, A. C. L., Vieira da Cunha, M., de Ferreira, M. A., dos Santos, D. C., de Lira, M. A., \& da Silva, M. C. (2015). Forage Potential of Cacti on Drylands. Acta Horticulturae, 1067, 181-186. https://doi.org/10.17660/ActaHortic.2015.1067.24

Fouche, H. J., \& Coetzer, G. M. (2015). Response of Cactus Pear (Opuntia spp.) Biomass Production to Fruit Load. Acta Horticulturae, 1067, 199-204.

https://doi.org/10.17660/ActaHortic.2015.1067.27

Friedlingstein, P., Jones, M. W., O’Sullivan, M., Andrew, R. M., Hauck, J., Peters, G. P. et al. (2019). Global Carbon Budget 2019. Earth System Science Data, 11, 1783-1838. https://doi.org/10.5194/essd-11-1783-2019

Gao, Y., Gao, X., \& Zhang, X. (2017). The $2^{\circ} \mathrm{C}$ Global Temperature Target and the Evolution of the Long-Term Goal of Addressing Climate Change-From the United Nations Framework Convention on Climate Change to the Paris Agreement. Engineering, 3, 272-278. https://doi.org/10.1016/J.ENG.2017.01.022

Gebeyehu, G., Soromessa, T., Bekele, T., \& Teketay, D. (2019). Carbon Stocks and Factors Affecting Their Storage in Dry Afromontane Forests of Awi Zone, Northwestern Ethiopia. Journal of Ecology and Environment, 43, Article No. 7. https://doi.org/10.1186/s41610-019-0105-8

Gibbs, H. K., Brown, S., Niles, J. O., \& Foley, J. A. (2007). Monitoring and Estimating Tropical Forest Carbon Stocks: Making REDD a Reality. Environmental Research Letters, 2, Article ID: 045023. https://doi.org/10.1088/1748-9326/2/4/045023

Githae, E. W., \& Mutiga, I. M. (2021). Ecological Restoration of Pastoral Landscapes in the Drylands of East Africa. Journal of Dryland Agriculture, 7, 34-41. https://doi.org/10.5897/JODA2020.0061

Glenday, J. (2008). Carbon Storage and Emissions Offset Potential in an African Dry Forest, the Arabuko-Sokoke Forest, Kenya. Environmental Monitoring and Assessment, 142, 85-95. https://doi.org/10.1007/s10661-007-9910-0

Gren, M., \& Aklilu, A. Z. (2016). Policy Design for Forest Carbon Sequestration: A Re- 
view of the Literature. Forest Policy and Economics, 70, 128-136.

https://doi.org/10.1016/j.forpol.2016.06.008

Harris, N. L., Brown, S., Hagen, S. C., Saatchi, S. S., Petrova, S., Salas, W., Lotsch, A. et al. (2012). Baseline Map of Carbon Emissions from Deforestation in Tropical Regions. Science, 336, 1573-1576. https://doi.org/10.1126/science.1217962

Henry, M., Picard, N., Trotta, C., Manlay, R., Valentini, R., Bernoux, M., \& Saint-André, L. (2011). Estimating Tree Biomass of Sub-Saharan African Forests: A Review of Available Allometric Equations. Silva Fennica, 45, 477-569.

https://hal.inrae.fr/hal-02651041 https://doi.org/10.14214/sf.38

Hoover, K., \& Riddle, A. A. (2020). Forest Carbon Primer. Congressional Research Service. https://fas.org/sgp/crs/misc/R46312.pdf

Houghton, R. A., \& Nassikas, A. A. (2018). Negative Emissions from Stopping Deforestation and Forest Degradation, Globally. Global Change Biology, 24, 350-359. https://doi.org/10.1111/gcb.13876

Houghton, R. A., House, J. I., Pongratz, J., Van Der Werf, G. R., Defries, R. S., Hansen, M. C., Ramankutty, N. et al. (2012). Carbon Emissions from Land Use and Land-Cover Change. Biogeosciences, 9, 5125-5142. https://doi.org/10.5194/bg-9-5125-2012

Hyvönen, P., Heikkinen, J., Haakana, H., Balazs, A., Muchiri, M. N., Kirongo, B. B., Ojuang, F. et al. (2016). Technical Report on Sampling Design Simulations for National Forest Resources Assessment in Kenya.

IMF (2019). Putting a Price on Pollution. Finance \& Development, 56, 16-19.

Intergovernmental Panel on Climate Change (IPCC) (2003). Good Practice Guidance for Land Use, Land-Use Change and Forestry. Institute for Global Environmental Strategies.

Intergovernmental Panel on Climate Change (IPCC) (2007). Climate Change 2007: Synthesis Report. Contribution of Working Groups I, II and III to the Fourth Assessment Report of the Intergovernmental Panel on Climate Change (104 p.). IPCC.

Intergovernmental Panel on Climate Change (IPCC) (2013). Summary for Policymakers. In T. F. Stocker, D. Qin, G. K. Plattner, M. Tignor, S. K. Allen, J. Boschung et al. (Eds.), Climate Change 2013. The Physical Science Basis. Contribution of Working Group I to the Fifth Assessment Report of the Intergovernmental Panel on Climate Change (pp. 3-29). Cambridge University Press.

Intergovernmental Panel on Climate Change (IPCC) (2018). Summary for Policymakers. In Global Warming of $1.5^{\circ} \mathrm{C}$. An IPCC Special Report on the Impacts of Global Warming of $1.5^{\circ} \mathrm{C}$ above Pre-Industrial Levels and Related Global Greenhouse Gas Emission Pathways, in the Context of Strengthening the Global Response to the Threat of climate Change, Sustainable Development, and Efforts to Eradicate Poverty (pp. 3-24). (In Press)

Intergovernmental Panel on Climate Change (IPCC) (2019). Climate Change and Land: An IPCC Special Report on Climate Change, Desertification, Land Degradation, Sustainable Land Management, Food Security, and Greenhouse Gas Fluxes in Terrestrial Ecosystems.

Iqbal, M. A., Hamid, A., Imtiaz, H., Rizwan, M., Imran, M., Sheikh, U. A. A., \& Saira, I. (2020). Cactus Pear: A Weed of Dry-Lands for Supplementing Food Security under Changing Climate. Planta Daninha, 38, e020191761. https://doi.org/10.1590/s0100-83582020380100040

Joos, F., \& Spahni, R. (2008). Rates of Change in Natural and Anthropogenic Radiative Forcing over the Past 20,000 Years. National Academy of Sciences, 105, 1425-1430. 
https://doi.org/10.1073/pnas.0707386105

Kagombe, J. K., \& Owour, B. (2007). Community Managed Forests: A Case of Mukogodo Forest, Laikipia. In Proceedings of the 1st National Participatory Forest Management Conference (pp. 21-28). Kenya Forestry Research Institute, Nairobi.

Kagombe, J. K., Karriuki, J. G., \& Luvanda, A.M. (2006). Socio-Economic and Natural Resources Baseline Survey in Mukogodo Landscape, Laikipia District. FORREMS Project Report. (Unpublished)

Keiluweit, M., Nico, P., Harmon, M. E., Mao, J., Pett-Ridge, J., \& Kleber, M. (2015). Long-Term Litter Decomposition Controlled by Manganese Redox Cycling. National Academy of Sciences, 112, E5253-E5260. https://doi.org/10.1073/pnas.1508945112

Kenya Forest Service (KFS) (2008). Integrated Forest Management Plan for Mukogodo forest.

Kenya Indigenous Forest Conservation Programme (KIFCON) (1994). Forest Inventory Report No. 15. Kenya Indigenous Forest Conservation Programme. Mukogodo Forest.

Lal, R. (2004). Carbon Sequestration in Dryland Ecosystems. Environmental Management, 33, 528-544. https://doi.org/10.1007/s00267-003-9110-9

Lal, R. (2019). Carbon Cycling in Global Drylands. Current Climate Change Reports, 5, 221-232. https://doi.org/10.1007/s40641-019-00132-Z

Lal, R., Lorenz, K., Hüttl, R. F., Schneider, B. U., \& von Braun, J. (2012). Terrestrial Biosphere as a Source and Sink of Atmospheric Carbon Dioxide. In Recarbonization of the Biosphere (pp. 1-15). Springer. https://doi.org/10.1007/978-94-007-4159-1_1

M'mboroki, K. G., Wandiga, S., \& Oriaso, S. O. (2018). Climate Change Impacts Detection in Dry Forested Ecosystem as Indicated by Vegetation Cover Change in Laikipia, of Kenya. Environmental Monitoring and Assessment, 190, 1-19. https://doi.org/10.1007/s10661-018-6630-6

MacDicken, K. G. (1997). A Guide to Monitoring Carbon Storage in Forestry and Agroforestry Projects. Winrock International Institute for Agricultural Development.

Marklund, L. G., \& Schoene, D. (2006). Global Assessment of Growing Stock, Biomass and Carbon Stock. Forest Resources Assessment Programme Working Paper 106, Food and Agriculture Organization of the United Nations Publication.

Meena, A., Bidalia, A., Hanief, M., Dinakaran, J., \& Rao, K. S. (2019). Assessment of Above- and Belowground Carbon Pools in a Semi-Arid Forest Ecosystem of Delhi, India. Ecological Processes, 8, 1-11. https://doi.org/10.1186/s13717-019-0163-y

Mendelsohn, R., Sedjo, R., \& Sohngen, B. (2012). Forest Carbon Sequestration. In Fiscal Policy to Mitigate Climate Change (pp. 89-102). International Monetary Fund.

Ministry of Environment and Forestry (MEF) (2019). The National Forest Reference Level for REDD+ Implementation, Kenya.

Ministry of Environment and Forestry (MEF) (2021). Kenya's Updated Nationally Determined Contribution (NDC) and JCM Activities.

Mokany, K., Raison, R. J., \& Prokushkin, A. S. (2006). Critical Analysis of Root: Shoot Ratios in Terrestrial Biomes. Global Change Biology, 12, 84-96.

https://doi.org/10.1111/j.1365-2486.2005.001043.x

Muchiri, M. N., \& Gachathi, F. N. (2006). Tree Inventory and Vegetation Survey of Mukogodo Landscape, Laikipia District. FORREMS Project Report, Kenya. (Unpublished)

Nam, V. T., Van Kuijk, M., \& Anten, N. P. (2016). Allometric Equations for Aboveground and Belowground Biomass Estimations in an Evergreen Forest in Vietnam. PLoS ONE, 11, e0156827. https://doi.org/10.1371/journal.pone.0156827

Ndambiri, J., Ngugi, J., \& Maina, E. (2020). Monitoring of Woodlands Biomass in Kenya: 
Technical Guide for Establishing Permanent Sample Plots for Monitoring above Ground Biomass in Kenya's Woodlands.

Nefzaoui, A., Louhaichi, M., \& Ben Salem, H. (2014). Cactus as a Tool to Mitigate Drought and to Combat Desertification. Journal of Arid Land Studies, 24, 121-124.

Ng'ethe, R., Kariuki, A., \& Opondo, C. (1997). Some Experience on Adaptive Research Input on Natural Resource Use: The Case of Gums and Resins in Mukogodo Rangelands, Laikipia District, Kenya. Aidgum, 9, 45.

Ngomanda, A., Obiang, N. L. E., Lebamba, J., Mavouroulou, Q. M., Gomat, H., Mankou, G. S., Picard, N. et al. (2014). Site-Specific versus Pantropical Allometric Equations: Which Option to Estimate the Biomass of a Moist Central African Forest? Forest Ecology and Management, 312, 1-9. https://doi.org/10.1016/j.foreco.2013.10.029

Njana, M. A. (2017). Indirect Methods of Tree Biomass Estimation and Their Uncertainties. Southern Forests: Journal of Forest Science, 79, 41-49. https://doi.org/10.2989/20702620.2016.1233753

Nobel, P. S. (1995). Recent Eco-Physiological Findings for Opuntia ficus-indica and Other Cacti. Journal of the Professional Association for Cactus Development, 1-11.

Pan, Y., Birdsey, R. A., Fang, J., Houghton, R., Kauppi, P. E., Kurz, W. A., Hayes, D. et al. (2011). A Large and Persistent Carbon Sink in the World's Forests. Science, 333, 988-993. https://doi.org/10.1126/science.1201609

Perez-Quezada, J. F., Delpiano, C. A., Snyder, K. A., Johnson, D. A., \& Franck, N. (2011). Carbon Pools in an Arid Shrubland in Chile under Natural and Afforested Conditions. Journal of Arid Environments, 75, 29-37. https://doi.org/10.1016/j.jaridenv.2010.08.003

Petersson, H., Holm, S., Ståhl, G., Alger, D., Fridman, J., Lehtonen, A., Mäkipää, R. et al. (2012). Individual Tree Biomass Equations or Biomass Expansion Factors for Assessment of Carbon Stock Changes in Living Biomass-A Comparative Study. Forest Ecology and Management, 270, 78-84. https://doi.org/10.1016/j.foreco.2012.01.004

Raghubanshi, A. S. (1991). Dynamics of Soil Biomass C, N, and P in a Dry Tropical Forest in India. Biology and Fertility of Soils, 12, 55-59. https://doi.org/10.1007/BF00369388

Rajput, B. S., Bhardwaj, D. R., \& Pala, N. A. (2017). Factors Influencing Biomass and Carbon Storage Potential of Different Land Use Systems along an Elevational Gradient in Temperate Northwestern Himalaya. Agroforestry Systems, 91, 479-486. https://doi.org/10.1007/s10457-016-9948-5

Simegn, T. Y., Soromessa, T., \& Bayable, E. (2014). Forest Carbon Stocks in Lowland Area of Simien Mountains National Park: Implication for Climate Change Mitigation. Science, Technology and Arts Research Journal, 3, 29-36. https://doi.org/10.4314/star.v3i3.5

Singh, K., \& Chand, P. (2012). Above-Ground Tree outside Forest (TOF) Phytomass and Carbon Estimation in the Semi-Arid Region of Southern Haryana: A Synthesis Approach of Remote Sensing and Field Data. Journal of Earth System Science, 121, 1469-1482. https://doi.org/10.1007/s12040-012-0237-z

Solomon, N., Birhane, E., Tadesse, T., Treydte, A. C., \& Meles, K. (2017). Carbon Stocks and Sequestration Potential of Dry Forests under Community Management in Tigray, Ethiopia. Ecological Processes, 6, 20. https://doi.org/10.1186/s13717-017-0088-2

Solomon, N., Pabi, O., Annang, T., Asante, I. K., \& Birhane, E. (2018). The Effects of Land Cover Change on Carbon Stock Dynamics in a Dry Afromontane Forest in Northern Ethiopia. Carbon Balance and Management, 13, 14. https://doi.org/10.1186/s13021-018-0103-7

Srinivas, K., \& Sundarapandian, S. (2019). Biomass and Carbon Stocks of Trees in Tropical Dry Forest of East Godavari Region, Andhra Pradesh, India. Geology, Ecology, and 
Landscapes, 3, 114-122. https://doi.org/10.1080/24749508.2018.1522837

Sun, W., \& Liu, X. (2020). Review on Carbon Storage Estimation of Forest Ecosystem and Applications in China. Forest Ecosystems, 7, 4.

https://doi.org/10.1186/s40663-019-0210-2

Tetemke, B. A., Birhane, E., Rannestad, M. M., \& Eid, T. (2019). Allometric Models for Predicting Aboveground Biomass of Trees in the Dry Afromontane Forests of Northern Ethiopia. Forests, 10, 1114. https://doi.org/10.3390/f10121114

Tiessen, H., Feller, C., Sampaio, E. V. S. B., \& Garin, P. (1998). Carbon Sequestration and Turnover in Semiarid Savannas and Dry Forest. Climatic Change, 40, 105-117. https://doi.org/10.1023/A:1005342932178

Trumper, K., Ravilious, C., \& Dickson, B. (2008). Carbon in Drylands: Desertification, Climate Change and Carbon Finance. A UNEP-UNDP-UNCCD Technical Note for Discussions at CRIC 7, Istanbul, Turkey, 3-14 November, 2008.

Ubuy, M. H., Eid, T., Bollandsås, O. M., \& Birhane, E. (2018). Aboveground Biomass Models for Trees and Shrubs of Exclosures in the Drylands of Tigray, Northern Ethiopia. Journal of Arid Environments, 156, 9-18. https://doi.org/10.1016/j.jaridenv.2018.05.007

Vashum, K. T., \& Jayakumar, S. (2012). Methods to Estimate Above-Ground Biomass and Carbon Stock in Natural Forests-A Review. Journal of Ecosystem \& Ecography, 2, 1-7. https://doi.org/10.4172/2157-7625.1000116

Webala, P. W., Muriuki, G., Lala, F., \& Bett, A. (2006). The Small Mammal Community of Mukogodo Forest, Kenya. African Journal of Ecology, 44, 363-370. https://doi.org/10.1111/j.1365-2028.2006.00634.x

Weiskittel, A. R., MacFarlane, D. W., Radtke, P. J., Affleck, D. L., Temesgen, H., Woodall, C. W., Coulston, J. W. et al. (2015). A Call to Improve Methods for Estimating Tree Biomass for Regional and National Assessments. Journal of Forestry, 113, 414-424. https://doi.org/10.5849/jof.14-091

Wekesa, C., Leley, N., Maranga, E., Kirui, B., Muturi, G., Mbuvi, M., \& Chikamai, B. (2016). Effects of Forest Disturbance on Vegetation Structure and Above-Ground Carbon in Three Isolated Forest Patches of Taita Hills. Open Journal of Forestry, 6, 142. https://doi.org/10.4236/ojf.2016.62013

World Bank (1993). Ecologically Sensitive Sites in Africa. Volume II: Eastern Africa. Compiled by the World Conservation Monitoring Centre for The World Bank. https://doi.org/10.5962/bhl.title.52367

World Bank (2020). State and Trends of Carbon Pricing 2020. World Bank.

Xu, L., Yu, G., He, N., Wang, Q., Gao, Y., Wen, D., Ge, J. et al. (2018). Carbon Storage in China's Terrestrial Ecosystems: A Synthesis. Scientific Reports, 8, Article No. 2806. https://doi.org/10.1038/s41598-018-20764-9

Zhao, M., Yang, J., Zhao, N., Liu, Y., Wang, Y., Wilson, J. P., \& Yue, T. (2019). Estimation of China's Forest Stand Biomass Carbon Sequestration Based on the Continuous Biomass Expansion Factor Model and Seven Forest Inventories from 1977 to 2013. Forest Ecology and Management, 448, 528-534. https://doi.org/10.1016/j.foreco.2019.06.036 


\section{Annex}

Overall biomass, carbon stocks and respective value in forest reserve, group ranches and conservancies in Mukogodo forest landscape under different vegetation types

\begin{tabular}{|c|c|c|c|c|c|c|c|c|c|}
\hline $\begin{array}{l}\text { Vegetation } \\
\text { type }\end{array}$ & $\begin{array}{l}\text { Biomass } \\
\left(\mathrm{TB} \mathrm{ha}^{-1}\right)\end{array}$ & $\begin{array}{l}\text { Carbon } \\
\left(\mathrm{TC} \mathrm{ha}^{-1}\right)\end{array}$ & $\begin{array}{l}\text { Total area } \\
\text { (ha) }\end{array}$ & $\begin{array}{c}\text { Total } \\
\text { biomass }(\mathrm{T})\end{array}$ & $\begin{array}{c}\text { Total } \\
\text { Carbon }(\mathrm{T})\end{array}$ & $\mathrm{CO}_{2 \mathrm{eq}}(\mathrm{T})$ & $\begin{array}{c}\text { Lowest } \\
\text { value (US\$) }\end{array}$ & $\begin{array}{c}\text { Moderate } \\
\text { value (US\$) }\end{array}$ & $\begin{array}{c}\text { Highest } \\
\text { value (US\$) }\end{array}$ \\
\hline \multicolumn{10}{|c|}{ 1. Mukogodo forest reserve } \\
\hline Closed forest & 273.82 & 128.70 & $17,625.06$ & $4,826,093.93$ & $2,268,345.22$ & $8,324,826.96$ & $16,649,653.93$ & $170,325,959.70$ & $665,986,157.18$ \\
\hline Open & 72.92 & 34.27 & 9167.67 & $668,506.50$ & $314,176.05$ & $1,153,026.11$ & $2,306,052.21$ & $23,590,914.15$ & $92,242,088.54$ \\
\hline Grassland & 92.13 & 43.30 & 1817.55 & $167,450.88$ & $78,699.92$ & $288,828.69$ & $577,657.38$ & $5,909,434.96$ & $23,106,295.04$ \\
\hline Shrubland & 23.70 & 11.14 & 593.01 & $14,054.34$ & 6606.13 & $24,244.50$ & $48,489.00$ & $496,042.52$ & $1,939,560.18$ \\
\hline Opuntia & 63.52 & 30.17 & 323.89 & $20,573.49$ & 9771.76 & $35,862.36$ & $71,724.73$ & $733,743.97$ & $2,868,989.12$ \\
\hline Bare land & 8.49 & 3.99 & 10.62 & 90.16 & 42.37 & 155.51 & 311.02 & 3181.77 & $12,440.95$ \\
\hline Total & 534.58 & 251.57 & $29,537.80$ & $5,696,769.30$ & $2,677,641.45$ & $9,826,944.14$ & $19,653,888.28$ & $201,059,277.06$ & $786,155,531.01$ \\
\hline \multicolumn{10}{|c|}{ 2. Laikipia ranches } \\
\hline Shrubland & 12.05 & 5.66 & 6996.60 & $84,309.03$ & $39,600.76$ & $145,334.77$ & $290,669.55$ & $2,973,549.49$ & $11,626,781.96$ \\
\hline Grassland & 14.87 & 6.99 & 7931.52 & $117,941.70$ & $55,441.32$ & $203,469.66$ & $406,939.32$ & $4,162,989.28$ & $16,277,572.96$ \\
\hline Closed forest & 273.82 & 128.70 & 2832.93 & $775,712.89$ & $364,598.09$ & $1,338,074.99$ & $2,676,149.99$ & $27,377,014.38$ & $107,045,999.52$ \\
\hline Open & 72.92 & 34.27 & $11,834.64$ & $862,981.95$ & $405,573.11$ & $1,488,453.32$ & $2,976,906.65$ & $30,453,755.01$ & $119,076,265.92$ \\
\hline Opuntia & 63.52 & 30.17 & 1683.09 & $106,909.88$ & $50,778.83$ & $186,358.29$ & $372,716.58$ & $3,812,890.59$ & $14,908,663.11$ \\
\hline Bare land & 8.49 & 3.99 & 685.62 & 5820.91 & 2735.62 & $10,039.74$ & $20,079.48$ & $205,413.07$ & $803,179.15$ \\
\hline Total & 445.67 & 209.78 & $31,964.40$ & $1,953,676.36$ & $918,727.73$ & $3,371,730.78$ & $6,743,461.57$ & $68,985,611.81$ & $269,738,462.61$ \\
\hline \multicolumn{10}{|c|}{ 3. Isiolo conservancies } \\
\hline Shrubland & 27.59 & 12.97 & $33,700.59$ & $929,799.28$ & $437,096.65$ & $1,604,144.71$ & $3,208,289.43$ & $32,820,800.85$ & $128,331,577.12$ \\
\hline Grassland & 22.61 & 10.63 & $20,682.09$ & $467,622.05$ & $219,850.62$ & $806,851.76$ & $1,613,703.53$ & $16,508,187.08$ & $64,548,141.06$ \\
\hline Closed forest & 273.82 & 128.70 & 2672.46 & $731,773.00$ & $343,945.60$ & $1,262,280.36$ & $2,524,560.72$ & $25,826,256.15$ & $100,982,428.75$ \\
\hline Open & 72.92 & 34.27 & $20,990.25$ & $1,530,609.03$ & $719,335.87$ & $2,639,962.63$ & $5,279,925.27$ & $54,013,635.49$ & $211,197,010.70$ \\
\hline Opuntia & 63.52 & 30.17 & 2314.71 & $147,030.38$ & $69,834.80$ & $256,293.72$ & $512,587.44$ & $5,243,769.48$ & $20,503,497.49$ \\
\hline Bare land & 8.49 & 3.99 & $11,247.30$ & $95,489.58$ & $44,876.73$ & $164,697.59$ & $329,395.18$ & $3,369,712.65$ & $13,175,807.05$ \\
\hline Total & 468.95 & 220.73 & $91,607.40$ & $3,902,323.32$ & $1,834,940.27$ & $6,734,230.78$ & $13,468,461.55$ & $137,782,361.70$ & $538,738,462.16$ \\
\hline Grand total & 1449.20 & 682.08 & $153,109.60$ & $11,552,768.98$ & $5,431,309.45$ & $19,932,905.70$ & $39,865,811.39$ & $407,827,250.57$ & $1,594,632,455.78$ \\
\hline
\end{tabular}

